\title{
Polygnathus sharyuensis nom. nov., a New Replacement Name for the Famennian (Upper Devonian) Polygnathus mawsonae Ovnatanova et al., 2017 (Conodonta)
}

\author{
N. S. Ovnatanova ${ }^{a, *}$, L. I. Kononova ${ }^{b, * *}$, L. S. Kolesnik ${ }^{c, * * *}$, and Yu. A. Gatovsky ${ }^{b, * * *}$ \\ ${ }^{a}$ All-Russia Research Institute of Petroleum Geology, Moscow, 105118 Russia \\ ${ }^{b}$ Department of Paleontology, Faculty of Geology, Moscow State University, Moscow, 119899 Russia \\ ${ }^{c}$ LLC “Kraton”, Syktyvkar, Komi Republic, 167005 Russia \\ *e-mail: ovnatanova@mail.ru \\ **e-mail:mvasil69@list.ru \\ ***e-mail: kolesnik.lud@yandex.ru \\ ****e-mail: gatovsky@geol.msu.ru
}

Received January 15, 2018; revised February 15, 2018; accepted February 20, 2018

DOI: $10.1134 / \mathrm{S} 0031030119020096$

Polygnathus mawsonae Ovnatanova et al., 2017 was named in honor of the famous specialist in conodonts Ruth Mawson and published in the paper on the Upper Devonian conodonts of northeastern European Russia (Ovnatanova et al., 2017, p. 1128). Subsequently R.T. Becker (Institut für Geologie und Paläontologie, Westfälische Wilhelms-Universität, Münster, Germany) kindly reported us that this species name had been preoccupied. He adduced data on the previously distinguished species and subspecies in his paper on the systematics of Polygnathus (Becker, 2012). Polygnathus labiosus mawsonae Long et Burrett, 1989 was first described from the Lower Devonian of Thailand (Long and Burrett, 1989). According to article 52.1 of the ICZN Code (International..., 1999; Mezhdunarodnyi..., 2000), we suggest for this species a new name Polygnathus sharyuensis Ovnatanova, Kononova, Kolesnik et Gatovsky, nom. nov. from the localities with this species in the basin of the Shar'yu River (Chernyshev Ridge, northeastern European Russia). The assignment of the species to Polygnathus and its holotype (Ovnatanova et al., 2017, pl. 48, figs. $7 \mathrm{a}, 7 \mathrm{~b})$ are preserved.

\section{ACKNOWLEDGMENTS}

We are grateful to R.T. Becker for recognizing the homonymy.

\section{REFERENCES}

Becker, R.T., The uncounted species of Polygnathus-plea for clear tracks through a taxonomic jungle, SDS Newsletter, 2012, no. 27, pp. 42-48.

International Code of Zoological Nomenclature: Fourth Edition, London: International Trust for Zoological Nomenclature, 1999.

Long, J.A. and Burrett, C.F., Early Devonian conodonts from the Kuan Tung Formation, Thailand: systematics and biogeographic considerations, Rec. Austral. Museum, 1989, vol. 41, no. 2, pp. 121-133.

Mezhdunarodnyi kodeks zoologicheskoi nomenklatury: Izdanie chetvertoe (International Code of Zoological Nomenclature: Fourth Edition), St. Petersburg: Zool. Inst. Ross. Akad. Nauk, 2000.

Ovnatanova, N.S., Kononova, L.I., Kolesnik, L.S., and Gatovsky, Yu.A., Upper Devonian conodonts of Northeastern European Russia, Paleontol. J., 2017, vol. 51, no. 10, pp. 973-1165.

Translated by A. Madison 